\title{
ALBION
}

\section{Contents of Volume 9}

Number 1, Spring, 1977

2 Checklist of Holdings of the Yale Center for Parliamentary History

Maija J. Cole

40 The English Fishing Industry in the Sixteenth Century: The Case of Great Yarmouth Robert Tittler

61 The Reform of Scottish Sheriffoms in the Eighteenth and Early Nineteenth Centuries

Ann E. Whetstone

72 Lord Bute, Newcastle, Prussia, and the Hague Overtures: A Re-examination Karl W. Schweizer

98 Sexual Deviance and Disaster During the Napoleonic Wars Arthur N. Gilbert

Number 2, Summer, 1977

115 Simon of Pattishall, Pioneer Professional Judge Ralph V. Turner

128 Recreation and Entertainment at the Cluniac Priory, Thetford 1497-1540

John Wasson

135 Compromise in Early Stuart Parliaments: The Case of the Short Parliament of 1640

Esther S. Cope

146 A Contemporary Chinese View of British History Nicholas R. Clifford

161 Samuel Smiles and the Origins of Self-Help: Reform and the New Enlightment

T. H. E. Travers

188 Communications

195 Reports of Proceedings 
Number 3, Fall, 1977

205 British Politics and the American Revolution Ian R. Christie

227 Social Structure, Voting Behavior, and Political Change in Victorian London

Marc B. Baer

242 The Political Demography of Cambridge, 1832-1868

Jeremy C. Mitchell and James Cornford

273 The Politics of William Morris's News From Nowhere

Trevor Lloyd

$288 \quad$ Reports of Proceedings

Number 4, Winter, 1977

297 Community Control and Puritan Politics in Elizabethan Suffolk

Paul S. Seaver

316 Cromwell, Cranmer and Lord Lisle: A Study in the Politics of Reform

Arthur J. Slavin

337 Commentary: The Papers by Professors Seaver and Slavin Wallace T. MacCaffrey

343 Continuity and Discontinuity; Professor Neale and the Two Worlds of Elizabethan Government

Lamar M. Hill

359 Herman Merivale and the Native Question, 1837-1861

David McNab

385 Reports of Proceedings

403 Index to Volume 9 


\section{New from Princeton}

Technological Change and the British Iron Industry,1700-1870

Charles K. Hyde

Costs, prices, profits, shrewd leaders, competition, new inventions, and productivity all figure in this comprehensive survey of the technological change in a key industry during the Industrial Revolution. "An important contribution to British economic history: it has rewritten the history of the iron industry by exploiting a great mass of primary sources in a quantitative way." - Donald N. McCloskey, University of Chicago $\$ 18.50$

Write for our new History Catalogue.
British

Rearmament in the Thirties

Politics and Profits Robert Paul Shay, Jr.

Here is a comprehensive analysis of rearmament under the Baldwin and Chamberlain governments. It reveals the primary determinants of events and provides important new information regarding the principal considerations underlying Chamberlain's policy of appeasement. "A lucid dissection of a modern democratically based, bureaucratic government floundering in the face of crisis. ... A deft blend of economic, political, and military history." - Library Journal Illus. • $\$ 18.50$

\section{Princeton University Press}

Princeton,

New Jersey 08540

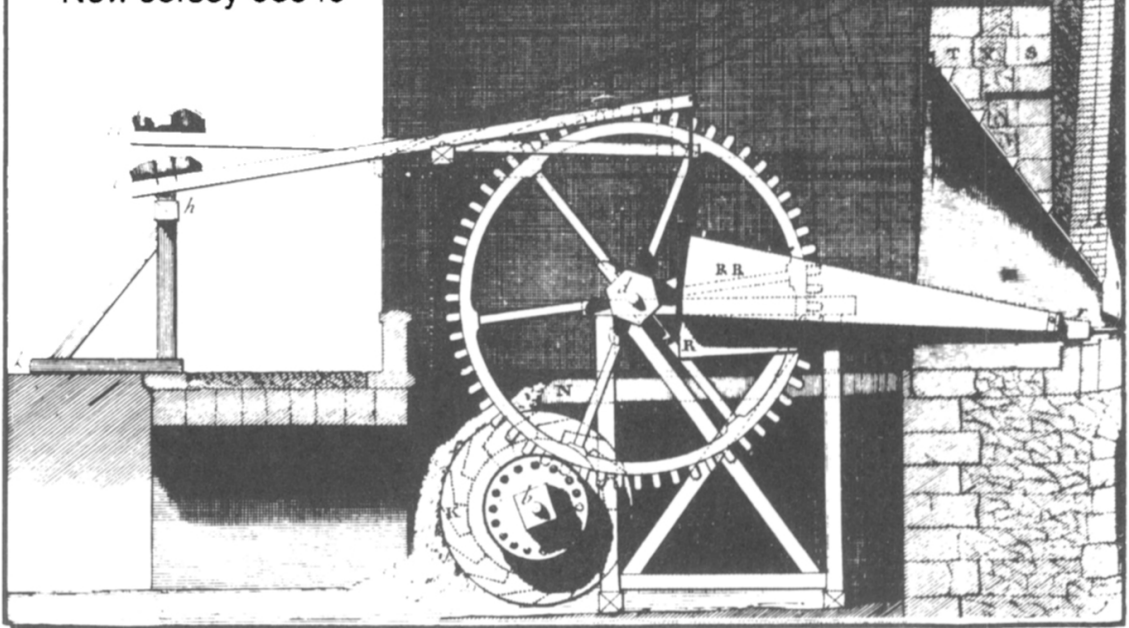


